\title{
Physico-chemical characterization of wines produced by different rootstock and Vitis vinifera cv. Tannat clones in vineyards of subtropical climate region
}

\author{
Willian dos Santos Triches ${ }^{1,2}$, Daniel Pazzini Eckhardt ${ }^{3}$, Elisandra Nunes da Silva ${ }^{3}$, Marcos Gabbardo ${ }^{3}$, Fabio \\ Clasen Chaves ${ }^{2}$, Jessica Fernanda Hoffmann², Giovana Paula Zandoná2, Cesar Valmor Rombaldi²
}

\author{
${ }^{1}$ IFSP, Instituto Federal de São Paulo, Campus São Roque CEP: 18136-540, São Roque-SP, Brazil \\ ${ }^{2}$ UFPel, Universidade Federal de Pelotas, CEP: 96010-000, Pelotas-RS, Brazil \\ ${ }^{3}$ Unipampa, Universidade Federal do Pampa, Campus Dom Pedrito, CEP: 96450-000, Dom Pedrito-RS, Brazil
}

\section{*Corresponding author: williantriches@yahoo.com.br}

\begin{abstract}
Tannat wine trees are well characterized in Uruguay and the French region of Madiran for their high colour and phenolic concentrations. In addition to the cultivar, the rootstock, clone and region of production can influence the phenolic concentrations of wines. In this context, this study evaluated the rootstocks 'SO4' (Vitis berlandieri x Vitis riparia), 'Gravesac' ('161-49C' $\mathrm{x}$ '3309C') and '3309C' (Vitis riparia x Vitis rupestris) grafted with Tannat cultivar clones ('Californian', '944', '717', '398' and '794') to assess the physicochemical, phenolic and sensorial composition of the wine produced in the Campanha Gaúcha (RS) region, Southern Brazil, in a subtropical climate region. A vineyard planted in 2007 was used in this study (for 3 years during 2015, 2016 and 2017). The wine composition and the sensorial profile were evaluated as dependent variables. This study showed that the rootstocks and the Tannat clones did not influence the dependent variables evaluated and that the genetic materials and their combinations presented high oenological potential, providing wines with high alcohol content, colour and phenolic compound concentrations. This study suggests the diversification of rootstocks and clones as a way of increasing genetic variability, avoiding the cultivation of a single rootstock and clone.
\end{abstract}

Keywords: Oenology; Phenolic Compounds; Red Wine; Rio Grande do Sul; Viticulture.

Introduction

The cultivar Tannat is emblematic of the Southwestern Region of France, particularly as the base of Madiran Appellations d'Origine wines. Similarly, Tannat is the main cultivar of the Region of Canelones in Uruguay, where it represents $27 \%$ of the vineyards (Gámbaro et al., 2001; Carrau et al., 2011; Disegna et al., 2014). In general, Tannat cultivar wines are characterized by a high concentration of flavan-3-ols, such as catechin, epicatechin, procyanidins, and anthocyanins, which are cited as responsible for the relatively high antioxidant activity of these wines (González-Neves et al., 2001; GonzálezNeves et al., 2012b). As a result, the Tannat wine consumer market has grown, especially among consumers searching for wines with a high structure and colour intensity and ageing potential (González-Neves et al., 2007; Boido et al., 2011). Furthermore, Tannat wines are among the richest in stilbenes, such as resveratrol, postulated as a functional property generator (Carrau et al., 2011).

In viticulture and winemaking, it is widely known that the compositions of grapes and wines are affected by edaphoclimatic conditions, genotype, and oenological management. In addition, due to the occurrence of phylloxera in nearly all of the countries producing the Tannat cultivar, most Tannat vineyards are planted using grafted vines. This also occurs in Campanha Gaúcha, Brazil, where although there are microregions with sandy soil (which would make prophylactic infection difficult), all vineyards are formed by grafted cv. Tannat. It is known that rootstocks and clones affect grape production and wine quality (González-Neves et al., 2004; González-Techera et al., 2004; Favre et al., 2014).

In the Brazilian winemaking context, the Campanha Gaúcha region (Brazil) is prominent in the production of 'Tannat' grapes and wines. This cultivar is among the emblematic grapes in this region, which has a similar climate as the regions of Canelones (Uruguay) and Madiran (France), except for the higher rainfall in Campanha Gaúcha than in Canelones and Madiran (Giuliani, 2016). Even though, several relevant questions about the local conditions of the Campanha Gaúcha region have not yet been answered, specifically questions about oenological responses to the rootstocks and clones of Tannat in this region (da Mota et al., 2009). 
In view of the above, three seasons were evaluated for agricultural productivity (Triches et al., 2017), and as a continuation of this research, we evaluated the chemical, phenolic and sensorial composition of wines produced by different rootstocks (SO4, Gravesac, and 3309C) and clones (Californian, 944, 717, 398 and 794) of cv. Tannat. These rootstocks and clones were chosen for the experiment because they showed good adaptability to the local biome by agronomic tests (Triches et al., 2016, 2017).

\section{Results and discussion}

\section{General Tannat wine physicochemical analyses}

The evaluation of the general wine composition of all treatments in 2015, 2016, and 2017 seasons verified that the average alcohol content was $13.21 \%(\mathrm{v} / \mathrm{v})$, while the average total acidity was 84.72 meq. $\mathrm{L}^{-1}$, the average $\mathrm{pH}$ was 3.76 , the average glycerol concentration was $10.35 \mathrm{~g} . \mathrm{L}^{-1}$, the average volatile acidity expressed as g. $\mathrm{L}^{-1}$ of acetic acid was $0.62 \mathrm{~g} . \mathrm{L}^{-1}$ and the average dry extract was $34.29 \mathrm{~g}^{-\mathrm{L}^{-1}}$ (Table 1 ). These values are consistent with the initial composition of the grape/must and with the winemaking process. Regarding the wines' general phenolic composition (Table 2), the average IPT value (total polyphenol index) was 70.03. The average concentration of total anthocyanins was $751.47 \mathrm{mg}$. $\mathrm{L}^{-1}$, the average concentration of total tannins was $2.63 \mathrm{~g}^{-1} \mathrm{~L}^{-1}$, the average colour intensity was 4.177 , the average ethanol index value was $8.04 \%$, the average gelatin index value was $48.12 \%$, and the average $\mathrm{HCl}$ index value was $28.20 \%$. The average wine composition agreed with the other works carried out with the Tannat cultivar and showed the remarkable characteristic of this cultivar, which is the high phenolic concentration (González-Neves et al., 2007; Boido et al., 2011; Carrau et al., 2011).

The alcohol contents found in the different combinations of rootstock/clone are consistent with oBrix and characterize grapes with good technological maturation, similar to works carried out in other regions where this cultivar is relevant (Rizzon and Miele, 2004; Hidalgo and Hidalgo, 2011; GonzálezNeves et al., 2012a), which provide wines with an alcohol content above $12.5 \%(\mathrm{v} / \mathrm{v})$. Concerning the total acidity (TA), all treatments presented high values for the red wine, demonstrating that a peculiar cultivar characteristic has high acidity (Rizzon and Miele, 2004; Carrau et al., 2011; Disegna et al., 2014). In the 2015 harvest, the 'Californian' clone showed excess of $\mathrm{K}$, as evidenced by rachis desiccation, and consequently, some of the bunches and the tips of bunches fell down. It was shown that wine with a higher $\mathrm{K}$ concentration results in a higher complexation of potassium with tartaric acid, reducing the total acidity and increasing $\mathrm{pH}$ values. However, the disturbance was not evidenced in the following seasons (Miele et al., 2009).

The content of glycerol confers softness to the palate. The glycerol is synthesized in a process linked to fermentation temperature and yeast strain. In all treatments of all harvests high and regular values were observed (Eustace and Thornton, 1987). Regarding variable volatile acidity, which is an indicator of grape sanitary quality, there was no difference between any treatment and the values remained within the normal range and below $1.2 \mathrm{gL}^{-1}$ (expressed in $\mathrm{gL}^{-1}$ acetic acid), indicating that the sanitary condition of the grape was not affected by the rootstock/clone. According to Rizzon and Miele (1996), the total dry extract represents a group of substances such as fixed acids, organic and mineral salts, polyalcohols, phenolic compounds, nitrogen compounds, sugars and polysaccharides. From the sensorial point of view, it is related to the wine structure. The total dry extract values were high and constant, regardless of the treatment, and superior to the total dry extract values of work conducted in Serra Gaúcha (Brazil) and similar to those observed in Uruguay (Rizzon and Miele, 2004; Piccardo and González-Neves, 2013).

There were no differences among the values of the total polyphenol index (IPT). The treatments all presented high values and demonstrated the suitability of the wine for maturing in oak barrels and bottle ageing (Rizzon and Miele, 2004; Carrau et al., 2011; Piccardo and González-Neves, 2013). Regarding the variable colour intensity, the treatments presented high values that were higher than the results obtained in Serra Gaúcha (Brazil) and in Campanha Gaúcha (Brazil), indicating wines with intense coloration independent of the rootstock/clone combination (Rizzon and Miele, 2004; Zocche, 2009). The colour tonality is indicated by the proportion (\%) of the yellow colour relative to red. It is strictly connected to the oxidation of anthocyanins. There was no difference between the treatments on colour tonality, resulting in intermediate values compared to those observed in Uruguay and similar values to those observed in Brazil (Rizzon and Miele, 2004; Favre et al., 2014; Gonzalez-Neves et al., 2015).

Regarding total anthocyanins, all treatments resulted in high concentrations of these compounds, with an average value of 751.47 mg. $\mathrm{L}^{-1}$. In comparison with works carried out on 'Tannat' Uruguayan wines, an average concentrations of 309 mg. $\mathrm{L}^{-1}$ was found by Favre et al. (2014). Disegna et al. (2014)

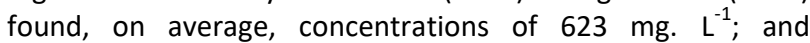
González-Neves et al. (2004) found, on average, concentrations of $752 \mathrm{mg} \cdot \mathrm{L}^{-1}$. Tannins, is important components of the Tannat cultivar, which inherits its denomination from these phenolic compounds. They were not affected by the rootstocks and clones as they revealed medium value of $2.63 \mathrm{~g}$. L ${ }^{-1}$ (Zamorra, 2003). The potential reactivity with these tannin proteins (gelatin index), which indicates the degree of astringency, presented an average value of $48.12 \%$, indicating wines of medium astringency are suitable for maturation in oak barrels (Zamorra, 2003). Regarding the high tannin polymerization percentage $(\mathrm{HCl}$ index), the treatments were appropriate for maturation in barrels, but they were also in the range of values, indicating that the wines can be consumed younger (Zamorra, 2003).

Although studies have shown the influence of rootstocks on the physicochemical and phenolic composition of wine, particularly because rootstocks affect the vine vigour and nutritional status of the canopy (da Mota et al., 2009), the results of the treatments with the Californian clone and different rootstocks (SO4 and Gravesac) indicated that 
rootstock had no influence on the wine composition, indicating the adaptation of both rootstocks with the cultivar Tannat to the local biome. Rogiers et al. (2004) showed that an analysis of the influence of the rootstock on the canopy should take the biome of the vineyard into account. This reinforces the basic assumption of the terroir concept, which is the expression of the interactions among biome $x$ grapevine $x$ management $x$ local culture.

Additionally, works such as Borges et al. (2014) have demonstrated the influence of the clone on grape composition. In an experiment carried out in Uruguay, Disegna et al. (2014), showed the influence of the Tannat clone on wine composition. However, in the present study, there was no difference among the evaluated clones. The results of this work indicate that all treatments affected typical grapes and wines cultivars, well-adapted to the region, providing wines with a high alcohol content and phenolic concentration, generating potential prospects for maturation and ageing (González-Neves et al., 2004; Carrau et al., 2011; Disegna et al., 2014; Favre et al., 2014). These findings are in line with works in cultivar Tannat in Uruguay (González-Neves et al., 2012b; Piccardo and González-Neves, 2013; Favre et al., 2014).

According to González-Techera et al. (2004) and Carrau et al. (2011), unlike other cultivars, the cultivar Tannat is highly homozygous. In their studies with a set of 15 microsatellites, the homozygosity was $53 \%$ in 'Tannat'. In contrast, the homozygosity was $6 \%$ for 'Pinot Noir', 20\% for 'Cabernet Franc' and 'Chardonnay' and 33\% for 'Cabernet Sauvignon', showing that 'Tannat' clones are genetically very close, and the ampelographic differences attributed to the different clones are probably due to epigenetic differences (Carrau et al., 2011). In the same study developed by González-Techera et al. (2004), only one microsatellite of 89 tested could clearly distinguish two groups of clones. Both the old Uruguayan clones and the French commercial clones were in each group, suggesting that the original sources of the clones had genetic proximity (González-Techera et al., 2004; Carrau et al., 2011). Two explanations for the relatively high uniformity of Tannat clones have been proposed based on the fact that the Tannat cultivar is historically a dominant variety in a particular region in Madiran (France) (Durquety and Houbart, 1982). The first explanation is that geographic isolation may have promoted natural self-fertilization events that would explain the high frequency of homozygous loci (Carrau et al., 2011). Second, geographical isolation provided the Tannat cultivar with homogenous external factors, such as climate, soil, and relief, a condition that reduced the plasticity of the vine in producing mutations (Hidalgo and Hidalgo, 2011).

\section{Chromatographic analysis - HPLC of Tannat wine phenolic compounds}

The proportions (\%) of individual forms of anthocyanins in the harvests of 2015, 2016 and 2017 were, on average, 68\% for malvidin, $19.53 \%$ for petunidine, $6.88 \%$ for peonidin, and $5.50 \%$ for delphinidin. The total amount of individual quantified anthocyanins was, on average, $401.08 \mathrm{mg}$. L-1 (Table 3). In addition, regardless of the treatment, the proportions (\%) of individual anthocyanins were in agreement with the cultivar, with a predominance of malvidin, followed by petunidin, a result previously observed in other studies (González-Neves et al., 2001, 2012b; Boido et al., 2011).

In the analysis of total anthocyanins, when the averages of the three harvests were evaluated, no difference was observed in either the proportions (\%) of individual anthocyanins or the total concentration of individual anthocyanins among the evaluated treatments, whereas the rootstock or clone had no influence. Furthermore, the mean concentrations of total individual anthocyanins in this work were similar to those in studies with the same cultivar in Uruguay (González-Neves et al., 2001, 2007, 2012b). The variability found among the same treatments in different harvests was expected due to variables that alter both the synthesis and form of the individual anthocyanins, which are chemically unstable (Zamorra, 2003; Ferrer et al., 2012; González-Neves et al., 2012b).

The analysing of concentrations of low-molecular-weight phenolic compounds (phenolic acids, flavonols, and resveratrol), in the years 2015, 2016 and 2017, showed that

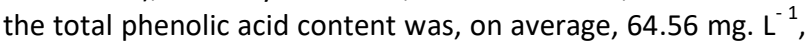
the mean resveratrol concentration was $1.01 \mathrm{mg}^{-1} \mathrm{~L}^{-1}$, while the average total flavonol content was $5.57 \mathrm{mg}^{-1} \mathrm{~L}^{-1}$ (Table 4). No differences were observed between treatments. The rootstock or Tannat clone did not influence the concentration of lowmolecular-weight phenolic compounds. Furthermore, the concentrations of phenolic acids were increased, and the concentrations of resveratrol and flavonols were similar to the observations of Favre et al. (2014) in Tannat cultivar.

Phenolic acids, according to Hidalgo (2011), are colourless, odourless and tasteless phenolic compounds. However, with oxidation over time, they can become volatile phenolic compounds and are perceived sensorially as characteristic odours. Depending on the concentration, volatile phenolic compounds can become a defect. However, these perceptions can only be verified in sensory evaluations of older wines, which was not the case in this experiment. None of the evaluators who performed the sensorial analysis detected these aromas in the wines of the present experiment.

Resveratrol is a phenolic compound widely cited for its benefits to human health, such as the prevention of cardiovascular diseases, cancer prevention, and neuroprotective action, which has been identified as the main factor of health protection in wines (Carrau et al., 2011). However, high concentrations of these compounds are not intrinsically bound to higher quality wines because its synthesis in the grape occurs due to the activation of plant defence mechanisms against biotic factors (pathogenic fungi, bacteria, and insects) and abiotic factors (temperature, radiation, wind, luminosity, water and salt stresses) (Penna and Hecktheuer, 2004). The Tannat cultivar is considered important due to its genetic character. This cultivar can synthesize and accumulate the highest amount of this molecule (Carrau et al., 2011), with concentrations of up to $6.75 \mathrm{mg}^{-1} \mathrm{~L}^{-1}$ (Lucena et al., 2010). The values detected here were lower in the range of the concentrations detected in Uruguay by Favre et al. (2014) $(0.72$ mg. $\mathrm{L}^{-1}$ ) and Carrau et al. (2011) (2.7 mg. L $\left.{ }^{-1}\right)$. 


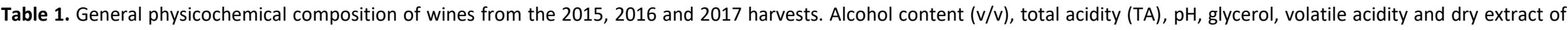
'Tannat' wines produced in vineyards with plants grafted on the rootstocks '3309', 'SO4', and 'Gravesac' and the clones 'Californian', '944', '717', '398', and '794'.

\begin{tabular}{|c|c|c|c|c|c|c|c|c|}
\hline \multirow[t]{2}{*}{ Variables } & \multirow[b]{2}{*}{ Harvest } & & \multicolumn{6}{|c|}{ Treatments } \\
\hline & & $\begin{array}{l}\text { Rainfall }^{\mathrm{a}} \\
\text { (mm) }\end{array}$ & $\begin{array}{l}3309 ' \\
' 944 '\end{array}$ & $\begin{array}{l}\text { 'SO4' } \\
\text { Cal. }\end{array}$ & $\begin{array}{l}\text { 'Gravesac' } \\
\text { Cal. }^{\text {b }}\end{array}$ & $\begin{array}{l}\text { 'Gravesac' } \\
\text { '717' }\end{array}$ & $\begin{array}{l}\text { 'Gravesac' } \\
\text { '398' }\end{array}$ & $\begin{array}{l}\text { 'Gravesac' } \\
\text { '794' }\end{array}$ \\
\hline \multirow[t]{5}{*}{ Alcohol (v/v) } & 2015 & 253.3 & $13.67 \mathrm{a}$ & $12.73 \mathrm{~b}$ & $12.68 \mathrm{~b}$ & $13.41 \mathrm{a}$ & $13.65 \mathrm{a}$ & $13.46 \mathrm{a}$ \\
\hline & 2016 & 165.7 & $13.27 \mathrm{abc}$ & $13.41 \mathrm{ab}$ & $13.77 \mathrm{a}$ & $13.17 \mathrm{bc}$ & $13.39 \mathrm{ab}$ & $12.77 \mathrm{c}$ \\
\hline & 2017 & 408.9 & $12.87 \mathrm{bc}$ & $13.56 \mathrm{a}$ & $13.74 \mathrm{a}$ & $12.57 \mathrm{c}$ & $13.35 a b$ & $12.48 \mathrm{c}$ \\
\hline & Mean & 275.9 & $13.27 \mathrm{~ns}$ & $13.23 \mathrm{~ns}$ & $13.39 \mathrm{~ns}$ & $13.05 \mathrm{~ns}$ & $13.43 \mathrm{~ns}$ & $12.90 \mathrm{~ns}$ \\
\hline & SD & \pm 123.1 & \pm 0.4 & \pm 0.44 & \pm 0.62 & \pm 0.43 & \pm 0.16 & \pm 0.50 \\
\hline \multirow[t]{5}{*}{ Total acidity (meq. $\mathrm{L}^{-1}$ ) } & 2015 & 253.3 & $71.06 \mathrm{~b}$ & $84.40 \mathrm{a}$ & $80.00 \mathrm{a}$ & $71.06 \mathrm{~b}$ & $74.66 \mathrm{~b}$ & $75.06 \mathrm{~b}$ \\
\hline & 2016 & 165.7 & $96.40 \mathrm{~ns}$ & $96.40 \mathrm{~ns}$ & $99.06 \mathrm{~ns}$ & $97.73 \mathrm{~ns}$ & $99.06 \mathrm{~ns}$ & $99.46 \mathrm{~ns}$ \\
\hline & 2017 & 408.9 & 77.73 ns & $81.06 \mathrm{~ns}$ & $81.60 \mathrm{~ns}$ & $79.46 \mathrm{~ns}$ & $80.00 \mathrm{~ns}$ & 80.93 ns \\
\hline & Mean & 275.9 & $81.73 \mathrm{~ns}$ & $87.28 \mathrm{~ns}$ & $86.88 \mathrm{~ns}$ & $82.75 \mathrm{~ns}$ & $84.57 \mathrm{~ns}$ & $85.15 \mathrm{~ns}$ \\
\hline & SD & \pm 123.1 & \pm 13.13 & \pm 8.06 & \pm 10.57 & \pm 13.63 & \pm 12.82 & \pm 12.73 \\
\hline \multirow[t]{5}{*}{$\mathrm{pH}$} & 2015 & 253.3 & $4.15 \mathrm{a}$ & $3.86 \mathrm{~b}$ & $3.87 \mathrm{~b}$ & $4.08 \mathrm{a}$ & $4.10 \mathrm{a}$ & $4.15 \mathrm{a}$ \\
\hline & 2016 & 165.7 & $3.70 \mathrm{~ns}$ & $3.64 \mathrm{~ns}$ & $3.57 \mathrm{~ns}$ & $3.66 \mathrm{~ns}$ & $3.63 \mathrm{~ns}$ & $3.60 \mathrm{~ns}$ \\
\hline & 2017 & 408.9 & $3.69 \mathrm{~ns}$ & $3.58 \mathrm{~ns}$ & $3.57 \mathrm{~ns}$ & $3.68 \mathrm{~ns}$ & $3.69 \mathrm{~ns}$ & $3.68 \mathrm{~ns}$ \\
\hline & Mean & 275.9 & $3.84 \mathrm{~ns}$ & $3.69 \mathrm{~ns}$ & $3.67 \mathrm{~ns}$ & $3.80 \mathrm{~ns}$ & $3.80 \mathrm{~ns}$ & $3.81 \mathrm{~ns}$ \\
\hline & SD & \pm 123.1 & \pm 0.26 & \pm 0.14 & \pm 0.17 & \pm 0.23 & \pm 0.25 & \pm 0.29 \\
\hline \multirow{5}{*}{$\begin{array}{l}\text { Glycerol } \\
\left(\mathrm{g} \cdot \mathrm{L}^{-1}\right)\end{array}$} & 2015 & 253.3 & $10.13 a$ & $9.57 \mathrm{ab}$ & $9.15 \mathrm{~b}$ & $9.93 a$ & $10.05 \mathrm{a}$ & $9.87 \mathrm{a}$ \\
\hline & 2016 & 165.7 & $12.30 \mathrm{ab}$ & $12.80 \mathrm{a}$ & $12.93 \mathrm{a}$ & $12.36 \mathrm{ab}$ & $12.56 a b$ & $12.1 \mathrm{~b}$ \\
\hline & 2017 & 408.9 & $8.44 \mathrm{~b}$ & $9.05 \mathrm{a}$ & $9.40 \mathrm{a}$ & $8.33 \mathrm{~b}$ & $9.20 \mathrm{a}$ & $8.2 \mathrm{~b}$ \\
\hline & Mean & 275.9 & $10.29 \mathrm{~ns}$ & 10.47 ns & $10.49 \mathrm{~ns}$ & $10.20 \mathrm{~ns}$ & $10.62 \mathrm{~ns}$ & 10.07 ns \\
\hline & SD & \pm 123.1 & \pm 1.93 & \pm 2.03 & \pm 2.11 & \pm 2.02 & \pm 1.71 & \pm 1.93 \\
\hline \multirow[t]{5}{*}{ Volatile acidity ${ }^{\mathrm{c}}\left(\mathrm{g} \cdot \mathrm{L}^{-1}\right)$} & 2015 & 253.3 & $0.63 \mathrm{bc}$ & $0.83 a$ & $0.75 a b$ & $0.57 c$ & $0.60 \mathrm{c}$ & $0.60 \mathrm{c}$ \\
\hline & 2016 & 165.7 & $0.66 a b$ & $0.60 a b$ & $0.50 \mathrm{~b}$ & $0.70 \mathrm{a}$ & $0.60 a b$ & $0.70 \mathrm{a}$ \\
\hline & 2017 & 408.9 & $0.58 \mathrm{~ns}$ & $0.58 \mathrm{~ns}$ & $0.56 \mathrm{~ns}$ & $0.63 \mathrm{~ns}$ & 0.63 ns & $0.58 \mathrm{~ns}$ \\
\hline & Mean & 275.9 & $0.62 \mathrm{~ns}$ & $0.67 \mathrm{~ns}$ & $0.60 \mathrm{~ns}$ & $0.63 \mathrm{~ns}$ & $0.61 \mathrm{~ns}$ & $0.62 \mathrm{~ns}$ \\
\hline & SD & \pm 123.1 & \pm 0.04 & \pm 0.13 & \pm 0.13 & \pm 0.06 & \pm 0.01 & \pm 0.06 \\
\hline \multirow[t]{5}{*}{ Dry extract (mg. $\left.\mathrm{L}^{-1}\right)$} & 2015 & 253.3 & $35.80 \mathrm{a}$ & $32.07 \mathrm{~b}$ & $31.73 \mathrm{~b}$ & $34.47 \mathrm{ab}$ & $35.40 \mathrm{a}$ & $36.30 \mathrm{a}$ \\
\hline & 2016 & 165.7 & $34.73 \mathrm{~ns}$ & $34.36 \mathrm{~ns}$ & 34.53 ns & 34.93 ns & 35.13 ns & 34.03 ns \\
\hline & 2017 & 408.9 & - & - & - & - & - & - \\
\hline & Mean & 275.9 & $35.26 \mathrm{~ns}$ & $33.21 \mathrm{~ns}$ & $33.13 \mathrm{~ns}$ & $34.70 \mathrm{~ns}$ & $35.26 \mathrm{~ns}$ & $35.16 \mathrm{~ns}$ \\
\hline & SD & \pm 123.1 & \pm 0.75 & \pm 1.61 & \pm 1.97 & \pm 0.32 & \pm 0.19 & \pm 1.60 \\
\hline
\end{tabular}

Averages followed by the same letter, in the same
cVolatile acidity expressed as g. $\mathrm{L}^{-1}$ of acetic acid. 


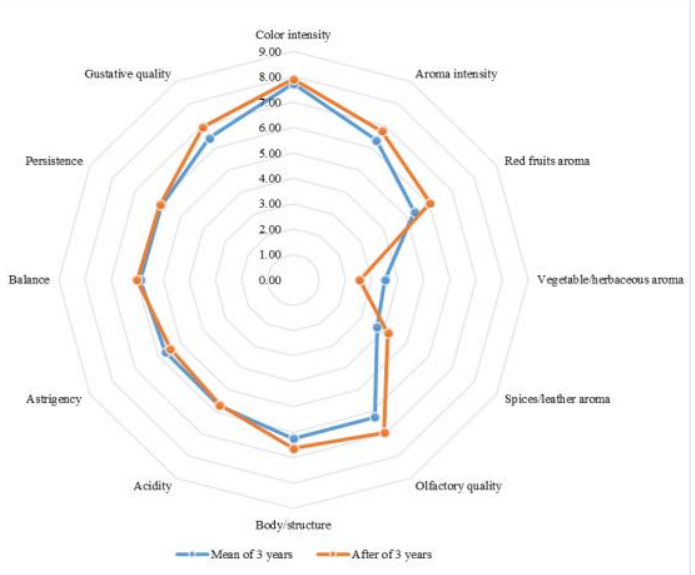

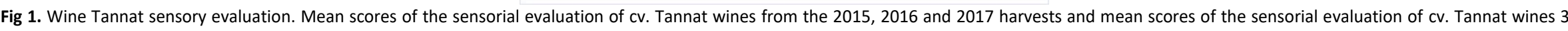

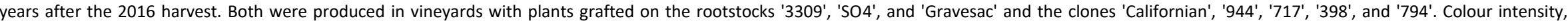

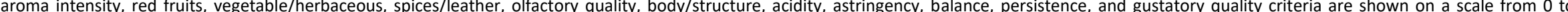

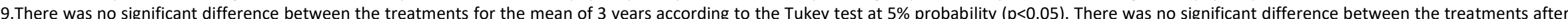
of 3 years according to the Tukey test at $5 \%$ probability $(p<0.05)$.

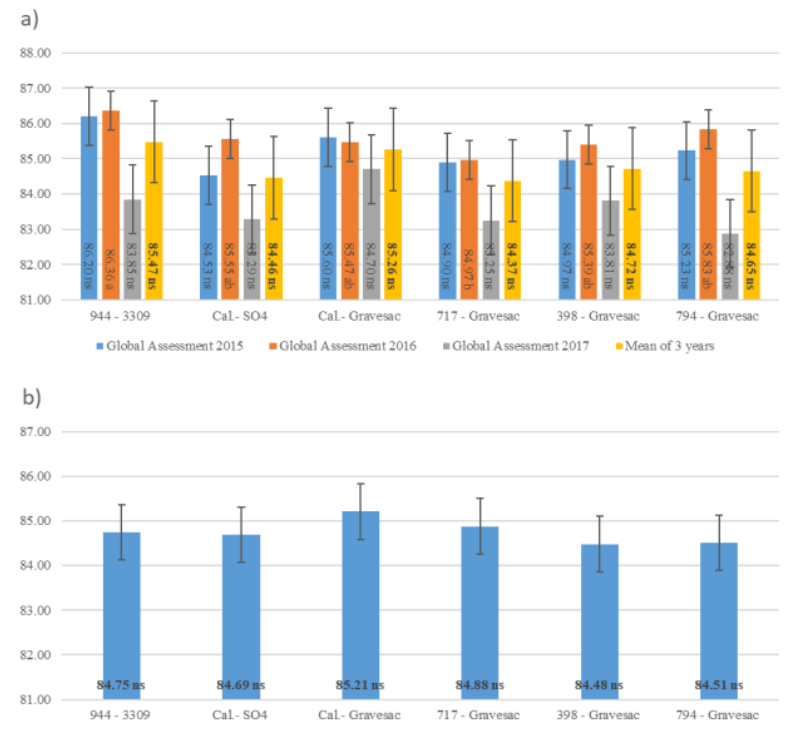

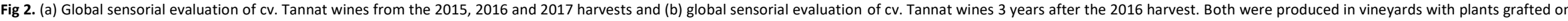
the rootstocks '3309', 'SO4', and 'Graves and the clones 'Californian', '944', '717' '398', and '794'. Global rating grades range from 0 to 100. Means followed by the same letter, in a column of the same colour, do not differ according to Tukey's test at $5 \%$ probability $(\mathbf{p}<0.05)$. Ns $=$ not significant. 


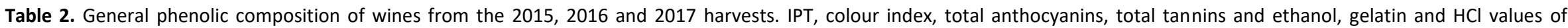
'Tannat' wines produced in vineyards with grafted plants in the rootstocks '3309', 'SO4', and 'Gravesac' and the clones 'Californian', '944', '717', '398', and '794'.

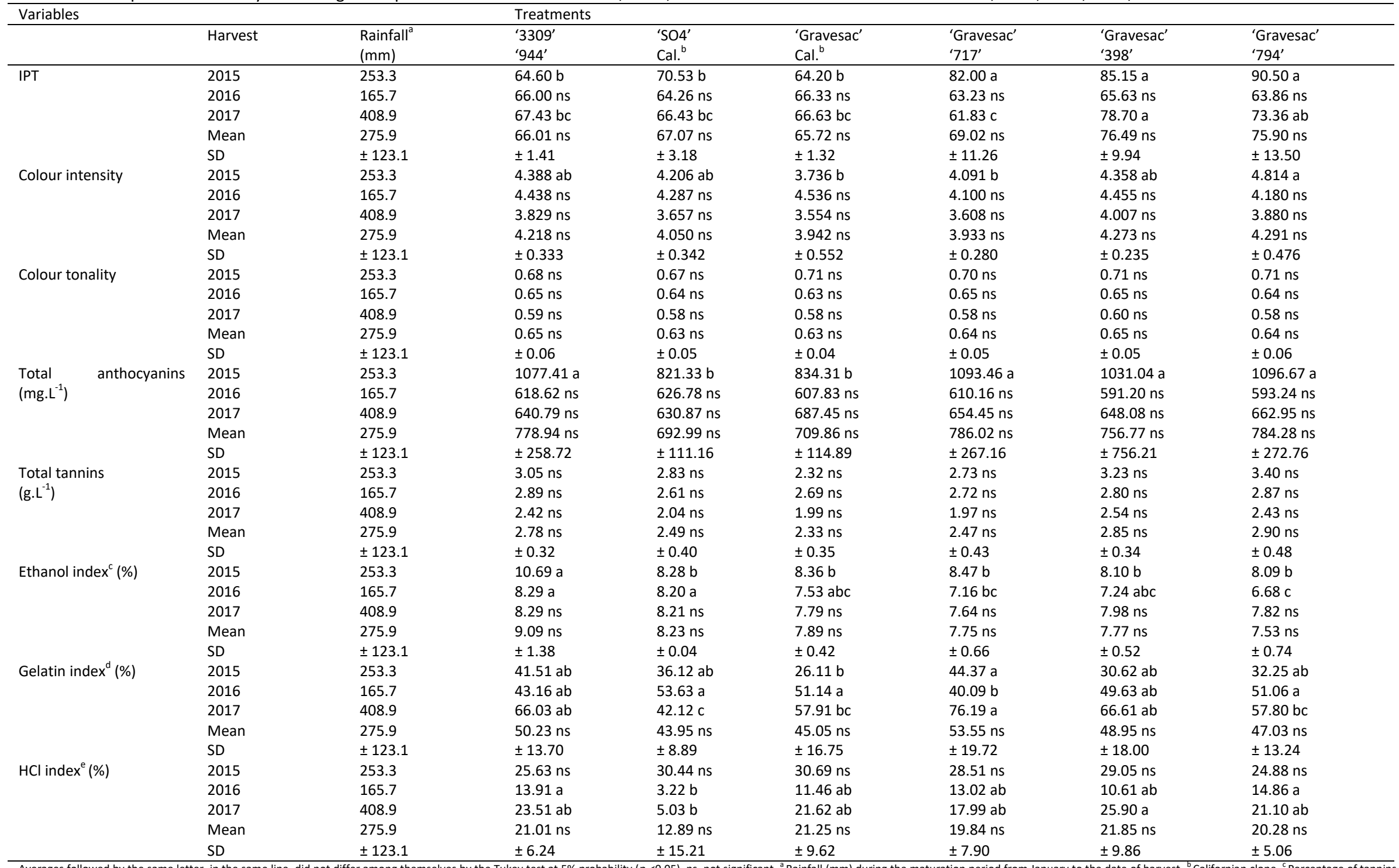

that are combined with polysaccharides. ${ }^{d}$ Percentage of tannins capable of reacting with proteins, these are astringent tannins. ${ }^{e}$ Percentage of high degree polymerization tannins. 


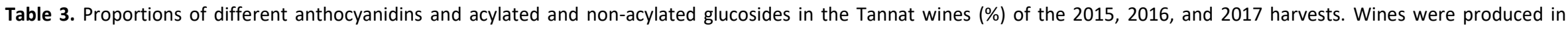
vineyards with plants grafted on the rootstocks '3309', 'SO4', and 'Gravesac' and Tannat clones 'Californian', '944', '717', '398', and '794'.

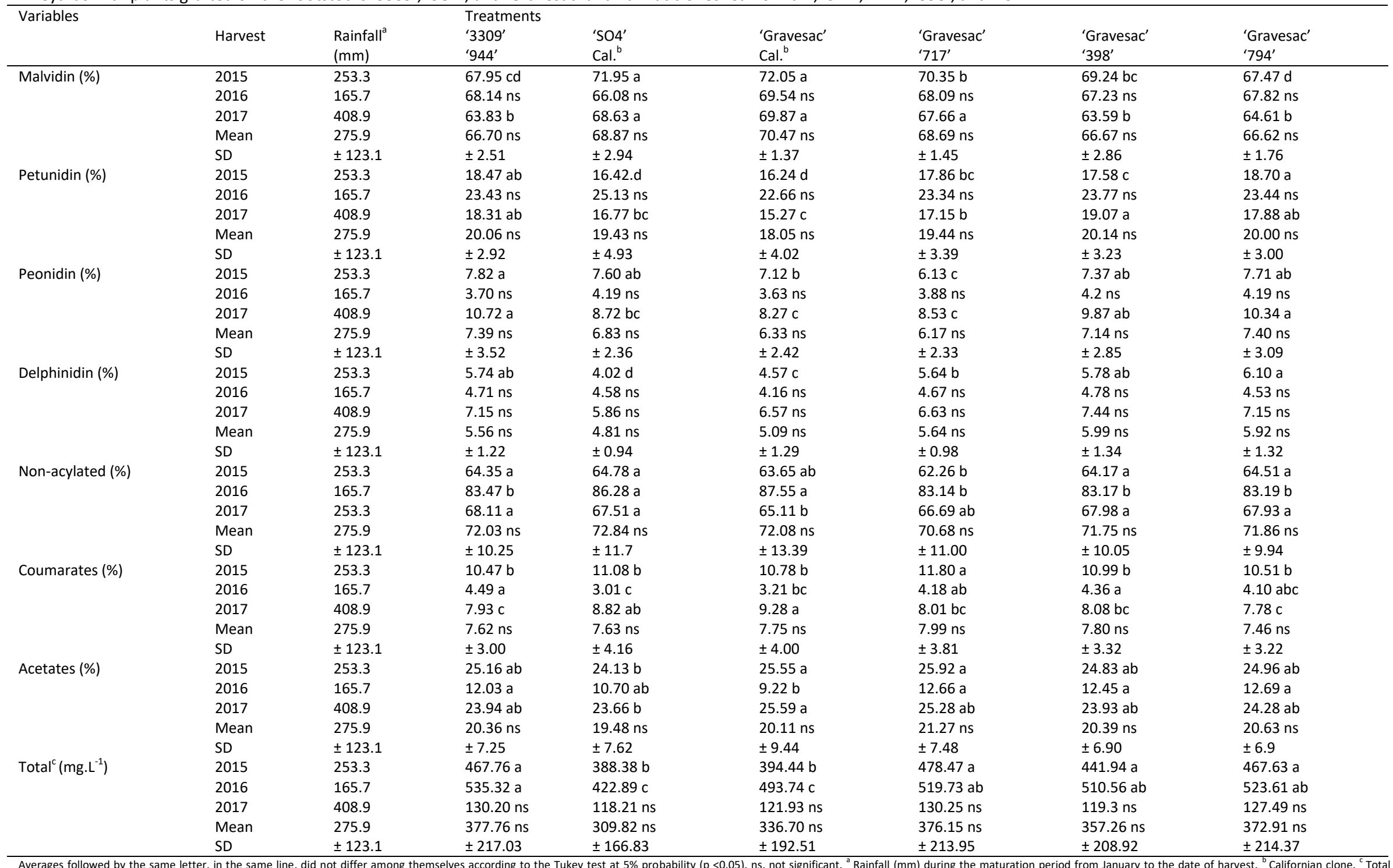
quantified individual anthocyanins. 


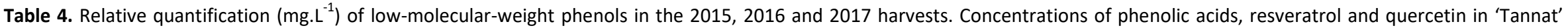
wines produced in vineyards with plants grafted on the rootstocks '3309', 'SO4', and 'Gravesac' and the clones 'Californian', '944', '717', '398', and '794'.

\begin{tabular}{|c|c|c|c|c|c|c|c|c|}
\hline \multirow[t]{2}{*}{ Variables } & \multicolumn{5}{|c|}{ Treatments } & \multirow[b]{2}{*}{$\begin{array}{l}\text { 'Gravesac' } \\
\text { '717' }\end{array}$} & \multirow[b]{2}{*}{$\begin{array}{l}\text { 'Gravesac' } \\
\text { '398' }\end{array}$} & \multirow[b]{2}{*}{$\begin{array}{l}\text { 'Gravesac' } \\
\text { '794' }\end{array}$} \\
\hline & Harvest & $\begin{array}{l}\text { Rainfall }^{\text {a }} \\
(\mathrm{mm})\end{array}$ & $\begin{array}{l}\text { '3309' } \\
\text { '944' }\end{array}$ & $\begin{array}{l}\text { 'SO4' } \\
\text { Cal. }^{\text {b }}\end{array}$ & $\begin{array}{l}\text { 'Gravesac' } \\
\text { Cal. }^{\text {b }}\end{array}$ & & & \\
\hline \multirow[t]{5}{*}{ Caffeic acid } & 2015 & 253.3 & $31.83 \mathrm{a}$ & $22.04 \mathrm{c}$ & $20.94 \mathrm{c}$ & $32.73 \mathrm{a}$ & $31.11 \mathrm{a}$ & $27.57 \mathrm{~b}$ \\
\hline & 2016 & 165.7 & 31.64 a & 20.76 b & $20.90 \mathrm{~b}$ & 29.99 a & $31.05 \mathrm{a}$ & $29.93 \mathrm{a}$ \\
\hline & 2017 & 408.9 & $40.30 \mathrm{a}$ & $40.24 \mathrm{a}$ & $19.32 \mathrm{~b}$ & $36.17 \mathrm{a}$ & $44.72 \mathrm{a}$ & $41.64 \mathrm{a}$ \\
\hline & Mean & 275.9 & $34.59 \mathrm{~ns}$ & $27.68 \mathrm{~ns}$ & 20.38 ns & $32.96 \mathrm{~ns}$ & 35.62 ns & 33.04 ns \\
\hline & SD & \pm 123.1 & \pm 4.95 & \pm 10.90 & \pm 0.92 & \pm 3.10 & \pm 7.88 & \pm 7.53 \\
\hline \multirow[t]{5}{*}{ Syringic acid } & 2015 & 253.3 & 6.02 bc & $8.98 \mathrm{a}$ & $7.74 a b$ & $3.49 \mathrm{~cd}$ & $3.81 \mathrm{~cd}$ & $3.41 \mathrm{~d}$ \\
\hline & 2016 & 165.7 & $6.68 \mathrm{a}$ & $6.46 a$ & $7.15 \mathrm{a}$ & $3.62 b$ & $2.61 \mathrm{bc}$ & $2.07 c$ \\
\hline & 2017 & 408.9 & $24.18 \mathrm{a}$ & $18.54 \mathrm{~b}$ & $16.58 \mathrm{~b}$ & $23.49 \mathrm{a}$ & $20.74 a b$ & $21.23 a b$ \\
\hline & Mean & 275.9 & $12.29 \mathrm{~ns}$ & $11.32 \mathrm{~ns}$ & $10.49 \mathrm{~ns}$ & $10.20 \mathrm{~ns}$ & $9.05 \mathrm{~ns}$ & $8.90 \mathrm{~ns}$ \\
\hline & SD & \pm 123.1 & \pm 10.29 & \pm 6.37 & \pm 5.28 & \pm 11.50 & \pm 10.13 & \pm 10.69 \\
\hline \multirow[t]{5}{*}{ P-coumaric acid } & 2015 & 253.3 & $7.95 \mathrm{a}$ & $6.02 \mathrm{~b}$ & $4.75 \mathrm{c}$ & $7.70 \mathrm{a}$ & $6.90 a b$ & $6.23 \mathrm{~b}$ \\
\hline & 2016 & 165.7 & $6.43 a b$ & $6.48 \mathrm{a}$ & $5.44 \mathrm{abc}$ & $5.55 a b c$ & $4.46 \mathrm{bc}$ & $3.67 c$ \\
\hline & 2017 & 408.9 & $8.23 b c$ & $10.21 \mathrm{ab}$ & $4.56 \mathrm{c}$ & $13.55 \mathrm{a}$ & $9.25 a b$ & $9.12 \mathrm{~b}$ \\
\hline & Mean & 275.9 & $7.53 \mathrm{~ns}$ & $7.57 \mathrm{~ns}$ & $4.94 \mathrm{~ns}$ & $8.93 \mathrm{~ns}$ & $6.87 \mathrm{~ns}$ & $6.34 \mathrm{~ns}$ \\
\hline & SD & \pm 123.1 & \pm 0.97 & \pm 2.30 & \pm 0.46 & \pm 4.14 & \pm 2.40 & \pm 2.72 \\
\hline \multirow[t]{5}{*}{ Ferulic acid } & 2015 & 253.3 & $14.96 \mathrm{a}$ & $14.63 \mathrm{a}$ & $12.8 \mathrm{ab}$ & $10.42 b$ & $13.07 \mathrm{a}$ & $13.81 \mathrm{a}$ \\
\hline & 2016 & 165.7 & 11.37 a & $8.07 a b$ & $6.85 b$ & $5.89 \mathrm{~b}$ & $5.39 \mathrm{~b}$ & $5.59 \mathrm{~b}$ \\
\hline & 2017 & 408.9 & $1.95 \mathrm{~b}$ & $2.36 \mathrm{~b}$ & $4.86 \mathrm{a}$ & $2.08 \mathrm{~b}$ & $1.41 \mathrm{~b}$ & $2.23 \mathrm{~b}$ \\
\hline & Mean & 275.9 & $9.42 \mathrm{~ns}$ & $8.35 \mathrm{~ns}$ & $8.17 \mathrm{~ns}$ & $6.13 \mathrm{~ns}$ & $6.62 \mathrm{~ns}$ & $7.21 \mathrm{~ns}$ \\
\hline & SD & \pm 123.1 & \pm 6.72 & \pm 6.14 & \pm 4.13 & \pm 4.18 & \pm 5.93 & \pm 5.95 \\
\hline \multirow[t]{5}{*}{ Gallic acid } & 2015 & 253.3 & $3.13 \mathrm{a}$ & $2.21 a b$ & $1.62 \mathrm{~b}$ & $2.73 \mathrm{a}$ & $2.73 a$ & $2.75 a$ \\
\hline & 2016 & 165.7 & 1.98 bc & $3.23 \mathrm{a}$ & $2.96 \mathrm{ab}$ & $2.47 \mathrm{abc}$ & $1.55 \mathrm{c}$ & $1.93 \mathrm{bc}$ \\
\hline & 2017 & 408.9 & $6.63 \mathrm{~b}$ & $2.61 \mathrm{~d}$ & $4.90 \mathrm{c}$ & $6.32 \mathrm{~b}$ & $8.99 a$ & $4.62 \mathrm{c}$ \\
\hline & Mean & 275.9 & $3.91 \mathrm{~ns}$ & $2.68 \mathrm{~ns}$ & $3.16 \mathrm{~ns}$ & $3.84 \mathrm{~ns}$ & $4.42 \mathrm{~ns}$ & $3.10 \mathrm{~ns}$ \\
\hline & SD & \pm 123.1 & \pm 2.42 & \pm 0.51 & \pm 1.65 & \pm 2.15 & \pm 4.00 & \pm 1.37 \\
\hline \multirow[t]{5}{*}{ Resveratrol } & 2015 & 253.3 & $0.75 \mathrm{~b}$ & $0.92 a b$ & $1.17 \mathrm{a}$ & $0.77 \mathrm{~b}$ & $0.71 b$ & $0.61 \mathrm{~b}$ \\
\hline & 2016 & 165.7 & $1.14 \mathrm{a}$ & $1.00 \mathrm{a}$ & $1.08 \mathrm{a}$ & $0.91 \mathrm{a}$ & $1.11 \mathrm{a}$ & $1.10 \mathrm{a}$ \\
\hline & 2017 & 408.9 & $1.69 \mathrm{ab}$ & $0.51 \mathrm{c}$ & $0.59 \mathrm{c}$ & $1.94 \mathrm{a}$ & $0.74 \mathrm{c}$ & $1.54 \mathrm{~b}$ \\
\hline & Mean & 275.9 & $1.19 \mathrm{~ns}$ & $0.81 \mathrm{~ns}$ & $0.94 \mathrm{~ns}$ & $1.20 \mathrm{~ns}$ & $0.85 \mathrm{~ns}$ & $1.08 \mathrm{~ns}$ \\
\hline & SD & \pm 123.1 & \pm 0.47 & \pm 0.26 & \pm 0.31 & \pm 0.64 & \pm 0.22 & \pm 0.46 \\
\hline \multirow[t]{5}{*}{ Quercetin } & 2015 & 253.3 & $2.56 \mathrm{~b}$ & $3.11 b$ & $8.00 \mathrm{a}$ & $4.90 \mathrm{~b}$ & $4.23 \mathrm{~b}$ & $7.72 \mathrm{a}$ \\
\hline & 2016 & 165.7 & $2.24 \mathrm{a}$ & $2.34 \mathrm{a}$ & $2.53 \mathrm{a}$ & $2.66 \mathrm{a}$ & $2.30 \mathrm{a}$ & $2.73 \mathrm{a}$ \\
\hline & 2017 & 408.9 & 7.69 bc & $12.11 \mathrm{a}$ & $11.99 \mathrm{a}$ & $5.85 \mathrm{c}$ & $7.34 \mathrm{c}$ & $10.12 a b$ \\
\hline & Mean & 275.9 & $4.16 \mathrm{~ns}$ & $5.85 \mathrm{~ns}$ & $7.50 \mathrm{~ns}$ & $4.47 \mathrm{~ns}$ & $4.62 \mathrm{~ns}$ & $6.85 \mathrm{~ns}$ \\
\hline & SD & \pm 123.1 & \pm 3.03 & \pm 5.43 & \pm 4.75 & \pm 1.64 & \pm 2.54 & \pm 3.76 \\
\hline
\end{tabular}




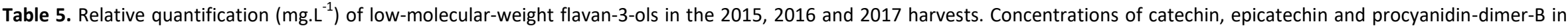
'Tannat' wines produced in vineyards with plants grafted on the rootstocks '3309', 'SO4', and 'Gravesac' and the clones 'Californian', '944', '717', '398', and '794'.

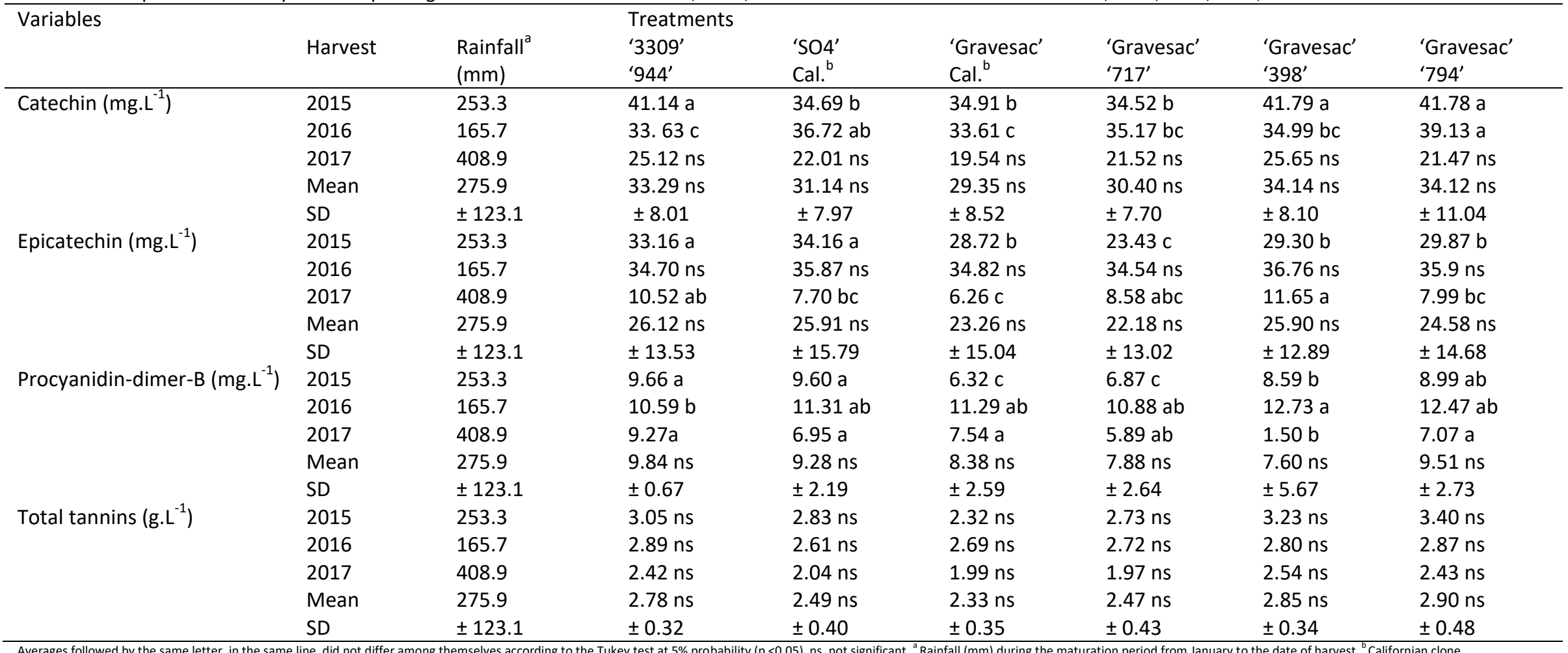


Evaluation of flavonol concentrations, the values agreed with those previously observed for the cultivar (Favre et al., 2014). Quercetin is an important flavonoid present in the human diet, possessing several potentially functional properties, such as antioxidant, anti-inflammatory, and antihistamine action (Behling et al., 2004). The presence of this molecule in wine is cited as important in colour evolution through copigmentation processes with anthocyanins (Abe et al., 2007). Low-molecular-weight flavan-3-ols are tannins with a high reactivity with saliva proteins and are; therefore, more astringent from the sensorial point of view Zamorra (2003). In the total quantification of these flavan-3-ols, we observed that there was no difference between the treatments in the averages of the three harvests, with higher values than those previously found for the cultivar by Favre et al. (2014) and Boido et al. (2011) but considered intermediate in concentration (Table 5). Such astringency was observed in the sensorial analysis, characterizing wines of medium/high astringency. On the other hand, the higher concentration of low-molecular-weight flavan-3-ols (tannins) was expected due to the joviality of the wine (analysed 10 months after vinification). According to Zamorra (2003), higher concentrations of low molecular weight flan-3-ols are related to wines with greater longevity because tannin polymerization in different reaction forms (polymerization by carbocation formation, formation of semiquinones and polymerization through the participation of ethanal) still occurs.

\section{Sensory evaluation of Tannat wines}

The sensorial analysis showed that there was no difference between the evaluated treatments in the tastings 10 months after the elaboration of the wines and in the tasting 3 years after the 2016 harvest. These results are presented as averages of the 3 seasons and the average of 3 years after the 2016 harvest (Fig 1). However, the sensorial profile of the wines from the 2016 vintage (after 3 years), showed qualitative gains, especially for olfactory attributes, with a lower perception of vegetal/herbaceous aroma and a higher perception of red fruits and spices/leather, indicating good evolution and longevity potential of the wines. The sensorial profile of the wines from this work is consistent with the descriptive profile of Tannat wines (Carrau et al., 2011; Vidal et al., 2016), with the exception of the relatively low astringency that detected here. The treatments presented global grades, with an average of 84.78 in the tastings 10 months after the elaboration of the wines, and 84.75 in tasting 3 years after the 2016 harvest (Fig 2), a value that characterizes wines with good sensorial quality. The results show the qualitative potential of the Tannat cultivar in the biome of Campanha Gaúcha, independent of the rootstock and clone.

\section{Materials and methods}

\section{Experimental area}

This study was carried out on 2015, 2016 and 2017 harvests in a commercial vineyard planted in 2007 in the city of Dom Pedrito, RS, Brazil ( $30^{\circ} 58^{\prime} \mathrm{S}, 54^{\circ} 40^{\prime} \mathrm{W}$, altitude $161 \mathrm{~m}$ )
(Instituto Brasileiro de Geografia e Estatística, 2018). The region is characterized by a humid subtropical climate, with an average annual rainfall of $1300 \mathrm{~mm}$. From January to March, the monthly rainfall varies from $100 \mathrm{~mm}$ to $400 \mathrm{~mm}$ (period from veraison to maturation). The average annual temperature is $17.9^{\circ} \mathrm{C}$, and the average temperature from January to March is $22.96 \circ \mathrm{C}$. The medium temperature range from January to March is $13.2^{\circ} \mathrm{C}$ (Instituto Nacional de Meteorologia, 2018). The soil classification in the vineyard location was plinthic allytic yellow red clay with corrugated relief (Streck et al., 2008). The rainfall was measured for the three evaluated crops $(2015,2016$ and 2017) in the period from veraison to harvest, comprising the period from January to the first half of March. The following precipitations values were found: $253 \mathrm{~mm}$ in the 2015 harvest, $165 \mathrm{~mm}$ in the 2016 harvest, and $408 \mathrm{~mm}$ in the 2017 harvest.

\section{Rootstocks and clones of the Tannat cultivar}

The vineyards were implanted with grafted cuttings produced with the rootstocks SO4 (Vitis berlandieri x Vitis riparia), Gravesac (161-49C x 3309C) and 3309C (Vitis riparia $\times$ Vitis rupestris). The tested Tannat clones were Californian, 944, 717, 398 and 794. Using these materials, combinations of rootstock and clone that have demonstrated good agronomic performance in the region during historical production were selected (Supplementary Table 1).

\section{Experimental design}

The experimental design consisted of 6 different treatments, each with its respective combinations of grafted plants. The combinations were as follows: Treatment 1: rootstock 3309C, clone 944; Treatment 2: rootstock SO4, Californian clone; Treatment 3: rootstock Gravesac and Californian clone; Treatment 4: rootstock Gravesac and clone 717; Treatment 5: rootstock Gravesac and clone 398; and Treatment 6: rootstock Gravesac and clone 794 (Triches et al., 2017).

Each experimental unit consisted of 10 plants, with three biological replicates for each treatment, for a total of 30 plants per treatment, and the plants (blocks of the rootstock $x$ clone combinations) within each vineyard were chosen in a homogeneous area.

The vineyards are installed with a spacing of $1 \mathrm{~m}$ (between plants) and $2.5 \mathrm{~m}$ (between rows) and north-south row orientation. The pruning system was used is double Guyot with $55 \mathrm{~cm}$ cordons.

\section{Harvesting and vinification}

In the three seasons (2015, 2016 and 2017), the harvest of all treatments was carried out on March 8th, when the grapes presented 22.86 Brix to 24.8 @Brix.

In each experimental unit, $13 \mathrm{~kg}$ of grapes were harvested and were kept in a cold room at $6 \circ \mathrm{C}$ and $80 \% \mathrm{RH}$ for $24 \mathrm{~h}$ prior to vinification. Destemming and crushing were carried out in a Modelo Top 5 destemmer (Enoveneta, Italy). The de-stemmed and crushed grapes were transferred to glass containers with a 
$14 \mathrm{~L}$ capacity. Potassium metabisulphite (100 mg. $\left.\mathrm{kg}^{-1}\right)$, active dry yeast (20 g.hL ${ }^{-1}$ Saccharomyces cerevisae, Zymaflore FX 10; Laffort; France), pectolytic enzymes (5 g.hL ${ }^{-1}$ Rohapect VC-R, AB Enzymes; Germany) and yeast nutrient (50 g.hL ${ }^{-1}$ Gesferm Plus, Amazon Group, Brazil) were added to the grapes.

The wines were made with the classic vinification technique, with eight days of maceration with skins and seeds. During maceration/fermentation, remontages were performed (three times a day), and the fermentation temperature was maintained between 20 and $22^{\circ} \mathrm{C}$. At the end of maceration, the free-run wine was drained, and the solid mass was pressed with the help of a vertical press. The free-run wine and the pressed wine were combined. After 48 hours, rackling was carried out to remove the sediments. The malolactic fermentation was occurred spontaneously (60 days duration) and after its conclusion, sulphur dioxide (concentration adjusted to $35 \mathrm{mg}$. L ${ }^{-1}$ of free $\mathrm{SO}_{2}$ ) was added to the wines. The wine evaluations were carried out 10 months after vinification.

\section{Wine physicochemical analyses}

\section{Classical physicochemical analyses}

The analyses were carried out 10 months after vinification. Total acidity, $\mathrm{pH}$, volatile acidity and glycerol analyses were performed using a Fourier Transform Infrared Spectrophotometer (FTIR) with WineScan ${ }^{\mathrm{TM}} \mathrm{SO}_{2}$ (FOSS, Denmark). The alcohol content, colour intensity, colour tonality and total dry extract concentration were analysed according to the method proposed by Organisation Internationale de la Vigne et du Vin (2013). Concentrations of total tannins, total anthocyanins, ethanol, gelatin index, and $\mathrm{HCl}$ index were determined according to methods proposed by Zamorra (2003). HPLC chromatography was used to identify and quantify the wine phenolic compounds.

\section{Chromatographic analysis (HPLC of wine phenolic compounds)}

An ultra-high-performance liquid chromatograph (UFLC, Shimadzu, Japan) coupled to a high-resolution mass spectrometer (quadrupole-time-of-flight) (Impact HD, Bruker Daltonics) was used to analyse the phenolic compounds (individual anthocyanins, phenolic acids, and flavonoids). These compounds were determined following the method described for Hoffmann et al. (2016), with the following modifications: the wines were diluted with $200 \mu \mathrm{L}$ of wine in $800 \mu \mathrm{L}$ of HPLC-grade methanol (Sigma-Aldrich) and filtered through a $0.45 \mu \mathrm{M}$ nylon membrane filter. Then, the compounds were separated using a C18 pre-column $(2.0 \times 4$ $\mathrm{mm})$ and a Luna C18 column $(2.0 \times 150 \mathrm{~mm}, 100 \AA, 3 \mu \mathrm{m})$ (Phenomenex Torrance, CA, USA). The mass spectrometer was operated in the ESI negative (phenolic acids flavonoids, flavan3-ols) and positive (anthocyanins) modes. Phenolic acid and flavonoid quantification was performed by using an external calibration curve with standards of each compound. The results were expressed in $\mu \mathrm{g} \mathrm{mL}^{-1}$. The anthocyanin content was quantified according to the pelargonidin external calibration curve, and the results were expressed in $\mu \mathrm{g} \mathrm{mL}^{-1}$ against an internal standard (reserpine) (Supplementary Fig 1). The analysis of low-molecular-weight flavan-3-ols was performed according to Delcambre and Saucier (2012). The compounds were separated using a C18 pre-column $(2.0 \times 4$ $\mathrm{mm})$ and a Luna C18 column $(2.0 \times 150 \mathrm{~mm}, 100 \AA, 3 \mu \mathrm{m})$ (Phenomenex Torrance, CA, USA). The following [M-H] molecules were monitored: (+) - catechin, $\mathrm{m} / \mathrm{z} 289.0718$; (-) epicatechin, $\mathrm{m} / \mathrm{z}$ 289.0718; procyanidin dimer $B, \mathrm{~m} / \mathrm{z}$ 577.1366. Flavan-3-ols were characterized by the UV/Vis spectrum (210-800 $\mathrm{nm}$ ), mass spectra and MSn fragmentation compared to the equipment library data and databases (Metlin, MassBank, Kegg Compounds). For quantification, a curve with the external $(-)$ epicatechin standard $(R 2=0.9999)$ was performed.

\section{Sensorial analysis}

A group of 10 trained and experienced evaluators performed the sensorial analysis, 10 months after the wine elaboration of each harvest, and a final evaluation of the 2016 harvest was conducted 3 years after wine elaboration. The quantitative descriptive analysis (QDA) method with a relative intensity tasting card was adopted (Stone and Sidel, 1993) using a numerical scale from 0 to 9 to determine the perception intensity degree of each evaluated characteristic. The evaluators also gave the wines a final grade on a scale from 0 to 100 .

\section{Statistical analysis}

The variance analyses and the classification of averages were performed with the Tukey test at $5 \%$ and analysed using the statistical software ASSISTAT Version 7.7 (Silva and Azevedo, 2016).

\section{Conclusion}

The rootstock or clone had no influence on the dependent variables evaluated (grape productivity and quality, composition and sensorial quality of wines), and all rootstocks and clones demonstrated high oenological potential in Campanha Gaúcha, Brazil, providing wines with a high alcohol content and high phenolic concentration. These results are relevant for agricultural production (yield and productivity), winemaking (quality wines), and the decision-making process of new vineyards, suggesting the diversification of rootstocks and clones as a way of increasing genetic variability, avoiding the cultivation of a single rootstock and clone.

\section{Acknowledgments}

We are grateful to Dunamis Wines and Vineyards, who kindly allowed part of this research to be carried out on their property, to the Amazon Enology Group for the donation of the oenological inputs used in the research, and to Conselho Nacional de Desenvolvimento Científico e Tecnológico (CNPq) 
and Coordenação de Aperfeiçoamento de Pessoal de Nível Superior (CAPES) for the financial support.

\section{References}

Abe LT, Da Mota RV, Lajolo FM, Genovese MI (2007) Compostos fenólicos e capacidade antioxidante de cultivares de uvas Vitis labrusca L. e Vitis vinifera L. Ciênc Tecnol Aliment. 27:394-400.

Behling EB, Sendão MC, Francescato HDC, Antunes LMG, Bianchi MLP (2004) Flavonóide quercetina: aspectos gerais e ações biológicas. Alim Nutr. 15:285-292.

Boido E, García-Marino M, Dellacassa E, Carrau F, RivasGonzalo JC, Escribano-Bailón MT (2011) Characterisation and evolution of grape polyphenol profiles of Vitis vinifera L. cV. Tannat during ripening and vinification. Aust J Grape Wine Res. 17:383-393.

Borges RS, Roberto SR, Yamashita F, Assis AM, Yamamotoi LY (2014) Produção e qualidade de frutos de clones de videira 'Concord'sobre diferentes porta-enxertos. Pesqui Agropecu Trop. 44:198-204.

Carrau F, Boido E, Gaggero C, Medina K, Fariña L, Disegna E, Dellacassa E (2011) Vitis vinifera Tannat, chemical characterization and functional properties. Ten years of research. In: Filip R (ed) Multidisciplinary approaches on food science and nutrition for the XXI century. Transworld Research Network, Kerala, India, 53-71.

da Mota RV, Souza CR, Favero AC, Silva CPC, Carmo EL, Fonseca AR, Regina MA (2009) Produtividade e composição físico-química de bagas de cultivares de uva em distintos porta-enxertos. Pesqui Agropecu Bras. 44:576-582.

Delcambre A, Saucier C (2012) Identification of new flavan-3-ol monoglycosides by UHPLC-ESI-Q-TOF in grapes and wine. J Mass Spectrom. 47:727-736.

Disegna E, Coniberti A, Ferrari V (2014) Clones de tannat. Instituto nacional de investigacion agropecuaria (INIA). Boletín de divulgacíon 109. http://www.ainfo.inia.uy/digital/bitstream/item/3805/1/bd109-2014.pdf.

Durquety PM, Houbart JP (1982) Two Tannat sports: "meunier" and "bulle". Progr Agric Vitic. 99:83-87.

Eustace R, Thornton RJ (1987) Selective hybridization of wine yeasts for higher yields of glycerol. Can J Microbiol. 33:112117.

Favre G, Peña-Neira Á, Baldi C, Hernández N, Traverso S, Gil G, González-Neves G (2014) Low molecular-weight phenols in Tannat wines made by alternative winemaking procedures. Food Chem. 158:504-512.

Ferrer M, Gonzalez-Neves G, Echeverria G, Camussi G (2012) Plant response and grape composition of Vitis vinifera $\mathrm{L}$. cV Tannat in different climatic regions. J Agric Sci Technol. 2:1252-1261.

Gámbaro A, Boido E, Zlotejablko A, Medina K, Lloret A, Dellacassa E, Carrau F (2001) Effect of malolactic fermentation on the aroma properties of Tannat wine. Aust J Grape Wine Res. 7:27-32.

Giuliani JC (2016) Caracterização edafoclimática e sua influência sobre a qualidade enológica em vinhedos da campanha Gaúcha. Thesis. Universidade Federal do Rio Grande do Sul, Porto Alegre.

González-Neves G, Barreiro L, Gil G, Franco J, Ferrer M, Moutounet M, Carbonneau A (2004) Anthocyanic composition of Tannat grapes from the south region of Uruguay. Anal Chim Acta. 513:197-202.

Gonzalez-Neves G, Favre G, Piccardo D, Ferrer M, Echeverria G (2015) Efecto de técnicas alternativas de maceración sobre el color y composición de vinos tintos de seis variedades de uva. Agrociencia. 19:57-68.

González-Neves G, Ferrer M, Gil G (2012a) Differentiation of Tannat, Cabernet Sauvignon and Merlot grapes from Uruguay according to their general composition and polyphenolic potential. Comun Sci. 3:41-49.

González-Neves G, Franco J, Barreiro L, Gil G, Moutounet M, Carbonneau A (2007) Varietal differentiation of Tannat, Cabernet-Sauvignon and Merlot grapes and wines according to their anthocyanic composition. Eur Food Res Technol. 225:111-117.

González-Neves G, Gil G, Favre G, Ferrer M (2012b) Influence of grape composition and winemaking on the anthocyanin composition of red wines of Tannat. Int J Food Sci Technol. 47:900-909.

González-Neves G, Gómez-Cordovés C, Barreiro L (2001) Anthocyanic composition of Tannat, Cabernet Sauvignon and Merlot young red wines from Uruguay. J Wine Res. 12:125133.

González-Techera A, Jubany S, de Léon IP, Boido E, Dellacassa E, Carrau FM, Hinrichsen P, Gaggero C (2004) Molecular diversity within clones of cv. Tannat (Vitis vinifera). Vitis. 43:179-185.

Hidalgo JT (2011) Tratado de enología. Ediciones MundiPrensa, Madrid.

Hidalgo LF, Hidalgo JT (2011) Tratado de viticultura. Ediciones Mundi-Prensa, Madrid.

Hoffmann J, Carvalho I, Barbieri R, Rombaldi C, Chaves F (2016) Butia spp. (Arecaceae) LC-MS-based metabolomics for species and geographical origin discrimination. J Agr Food Chem. 65:523-532.

Instituto Brasileiro de Geografia e Estatística (2018) Levantamento sistemático da produção agrícola. $\mathrm{ftp}: / / \mathrm{ftp}$.ibge.gov.br/Producao_Agricola/Levantamento_Siste matico_da_Producao_Agricola_\%5Bmensal\%5D/Fasciculo/2 017/lspa_201712.pdf.

Instituto Nacional de Meteorologia (2018) Instituto nacional de meteorologia.

http://www.inmet.gov.br/portal/index.php?r=estacoes/esta coesautomaticas.

Lucena APS, Nascimento RJB, Maciel JAC, Tavares JX, BarbosaFilho JM, Oliveira EJ (2010) Antioxidant activity and phenolics content of selected Brazilian wines. J Food Compost Anal. 23:30-36.

Miele A, Rizzon LA, Giovannini E (2009) Efeito do porta-enxerto no teor de nutrientes em tecidos da videira "cabernet sauvignon". Rev Bras Frutic. 31:1141-1149.

Organisation Internationale de la Vigne et du Vin (2013) International oenological codex. Organisation Internationale de la Vigne et du Vin, Paris, France. 
Penna NG, Hecktheuer LHR (2004) Vinho e saúde: uma revisão. Infarma. 16:64-67.

Piccardo D, González-Neves G (2013) Extracción de polifenoles y composición de vinos tintos Tannat elaborados por técnicas de maceración prefermentativa. Agrocienc Urug. 17:36-44.

Rizzon LA, Miele A (1996) Extrato seco total de vinhos brasileiros: comparação de métodos analíticos. Ciênc Rural. 26:297-300.

Rizzon LA, Miele A (2004) Avaliação da cv. Tannat para elaboração de vinho tinto. Ciênc Tecnol Aliment. 24:223229.

Rogiers SY, Hatfield JM, Keller M (2004) Irrigation, nitrogen, and rootstock effects on volume loss of berries from potted Shiraz vines. Vitis. 43:1-6.

Silva FDA, Azevedo CAV (2016) The assistat software version 7.7 and its use in the analysis of experimental data. Afr J Agric Res. 11:3733-3740.

Stone H, Sidel JL (1993) Sensory evoluation practices. Academic Pess, Flórida.

Streck EV, Kämpf N, Dalmolin RSD, Klamt E, Nascimento PC, Schneider P, Giasson E, Pinto LFS (2008) Solos do rio grande do sul. Emater/RS, Porto Alegre.
Triches W, Gabbardo M, Eckhardt D, Rombaldi C (2016) Agronomic responses of interaction between rootstocks and clones 'Tannat' in Campanha Gaúcha - RS region. Poster session presented at 39th World Vine and Wine Congress, Bento Gonçalves, 23-28 october 2016.

Triches WS, Gabbardo M, Eckhardt DP, Rombaldi CV (2017) Respostas agronômicas da interação entre porta-enxertos e clones do cv. Tannat em vinhedo da Campanha. Rev Bras Vitic Enol. 9:18-24.

Vidal L, Antúnez L, Giménez A, Medina K, Boido E, Ares G (2016) Dynamic characterization of red wine astringency: Case study with Uruguayan Tannat wines. Food Res Int. 82:128-135.

Zamorra F (2003) Elaboración y crianza del vino tinto: aspectos científicos y práticos. Ediciones Mundi-Prensa, Madrid.

Zocche RGS (2009) Potencial enológico de uvas Tannat, Cabernet Sauvignon e Merlot produzidas no município de Bagé - RS. Thesis. Universidade Federal de Pelotas, Pelotas. 